\title{
The partner perspective of the impact of pituitary diseases: results from a focus group study
}

\section{Introduction}

Patients with pituitary disease report impairments in Quality of Life (QoL).

From other chronic diseases, it is known that partners of patients also report QoL impairments, and that well-being of patients is associated with the well-being of their partners. To date, no data are available on the well-being of partners of patients with pituitary disease.

\section{Objective}

To elucidate well-being of partners of patients with pituitary disease.

\section{Methods}

Focus group conversations in groups of 4-6 partners of patients with pituitary disease (Cushing's disease (CD), non-functioning adenoma (NFA), acromegaly (ACRO), prolactinoma (PRL)). In two sessions, these groups discussed the impact of the pituitary disease of their partner on their own lives. Verbatim transcripts were analyzed using a grounded theory approach.

\section{Adaptation:}

"My partner no longer drives, I always have to. Sometimes I feel like a taxi driver".

Lack of sympathy from the social network: "People in your social environment say: it's not malignant, so it is nothing".

Issues with the desire to have children: "You have a certain expectation about your life, and you need to adjust that expectation".

\section{Insufficient information:}

"If it is explained to me how it works psychologically, than I would have a lot less difficulty, less burden, and it would cost less energy. That would benefit the relationship when it comes to what you have to offer a partner"

\section{Results}

From the focus group conversations, five themes were derived: worries related to the pituitary disease and medication, coping difficulties, relationship issues, social issues, and unmet needs regarding care. Most of the reported complaints were mentioned by all diagnostic groups (i.e., CD, ACRO, NFA, PRL), but some were disease-specific (see Table 1).

Table 1. Overview of reported categories categorized per pituitary disease

\begin{tabular}{|c|c|c|c|c|c|}
\hline \multirow[t]{2}{*}{ Category } & \multirow[t]{2}{*}{ Subcategory } & \multicolumn{4}{|c|}{ Pituitary disease of the ill partner } \\
\hline & & $\mathrm{CD}$ & ACRO & 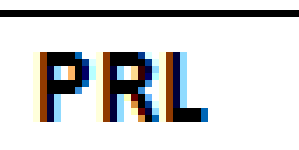 & NFA \\
\hline \multirow[t]{2}{*}{ Worries } & Related to pituitary disease & $\mathrm{x}$ & $\mathrm{x}$ & $\mathrm{x}$ & $\mathrm{x}$ \\
\hline & Related to medication & & $\mathrm{x}$ & $\mathrm{x}$ & \\
\hline \multirow[t]{4}{*}{ Coping difficulties } & $\begin{array}{l}\text { Uncertainty about comforting or } \\
\text { encouraging the ill partner }\end{array}$ & $\mathrm{x}$ & $\mathrm{x}$ & & $\mathrm{x}$ \\
\hline & Adaptation & $\mathrm{x}$ & $\mathrm{x}$ & $\mathrm{x}$ & $\mathrm{x}$ \\
\hline & High sense of responsibility & $\mathrm{x}$ & $\mathrm{x}$ & $\mathrm{x}$ & $\mathrm{x}$ \\
\hline & Differences in copings styles & $\mathrm{x}$ & & $\mathrm{x}$ & $\mathrm{x}$ \\
\hline \multirow[t]{5}{*}{ Relationship issues } & Changes in the relationship & $\mathrm{x}$ & $\mathrm{x}$ & $\mathrm{x}$ & $\mathrm{x}$ \\
\hline & Communication with ill partner & $\mathrm{x}$ & & $\mathrm{x}$ & $\mathrm{x}$ \\
\hline & Viewing the ill partner differently & & $\mathrm{x}$ & $\mathrm{x}$ & \\
\hline & Issues regarding sexuality & & $\mathrm{x}$ & $\mathrm{x}$ & $\mathrm{x}$ \\
\hline & Issues with the desire to have children & & $\mathrm{x}$ & $\mathrm{x}$ & $\mathrm{x}$ \\
\hline \multirow[t]{5}{*}{ Social issues } & $\begin{array}{l}\text { Difficulties in communication about the } \\
\text { disease }\end{array}$ & $\mathrm{x}$ & $x$ & $\mathrm{x}$ & $\mathrm{x}$ \\
\hline & Lack of sympathy from the environment & $\mathrm{x}$ & $\mathrm{x}$ & $\mathrm{x}$ & $\mathrm{x}$ \\
\hline & Changes in social network & $\mathrm{x}$ & & $\mathrm{x}$ & $\mathrm{x}$ \\
\hline & Negative impact on family & $\mathrm{x}$ & $\mathrm{x}$ & $\mathrm{x}$ & $\mathrm{x}$ \\
\hline & Negative impact on work & & & $\mathrm{x}$ & \\
\hline \multirow[t]{3}{*}{$\begin{array}{l}\text { Unmet needs } \\
\text { regarding care }\end{array}$} & Insufficient information & $\mathrm{x}$ & $\mathrm{x}$ & $\mathrm{x}$ & $\mathrm{x}$ \\
\hline & No recognition for certain complaints & & & $\mathrm{x}$ & $\mathrm{x}$ \\
\hline & $\begin{array}{l}\text { Dissatisfaction about aspects of medical } \\
\text { care }\end{array}$ & $x$ & $x$ & $x$ & $\mathrm{x}$ \\
\hline
\end{tabular}

Conclusions and future directions

This first focus group study in partners of patients with a pituitary disease illustrates the negative impact of pituitary diseases on well-being of partners and the impact on their lives. This study emphasizes the importance of not only paying attention to the psychosocial impact perceived by patients during clinical practice, but also to pay attention to their partners. The information obtained from this study can be used for the development of a disease-specific questionnaire for partners of patients with a pituitary disease, in order to further quantitatively assess their well-being, as well as for optimizing psychosocial care for patients and their partners.

Worries related to medication:

"The moment he stops his medication I see my old husband. But that disappears as soon as he starts again".

Negative impact on family:

"We currently experience that he is very tired and his patience runs out quickly. This be that shoulder to cry on, when you need to is also towards the children".

\section{Changes in the relationship:}

"I find that it changes your relationships anyway, yeah, the positivity is gone".

Uncertainty about accommodating or

"It is difficult to determine when you need to pull somebody up, or when to say 'don't be silly, get up, and do it'”. encouraging the patient: 